7. Reprod. Fert. (1966) 12, 561-564

BRIEF COMMUNICATION

\title{
THE STIMULATION OF FERTILE OESTRUS IN ANOESTROUS ROMNEY EWES. I
}

\author{
E. M. ROBERTS ANR D. G. EDGAR \\ School of Wool Technology, University of Nerw South Wales, Kensington, N.S.W., \\ Australia, and Ruakura Agricultural Research Centre, Hamilton, New Zealand \\ (Received 4th January 1966, revised 7th Fune 1966)
}

\begin{abstract}
Summary. Anoestrous Romney ewes were treated for 10 or 13 days with intra-vaginal sponges containing $400 \mathrm{mg}$ of progesterone or $40 \mathrm{mg}$ of 6-methyl-17-acetoxyprogesterone. Pregnant mare's serum gonadotrophin (PMSG) was injected subcutaneously on the 10th and 26th, or 13th and 29th days.

A more highly synchronized pattern of oestrus occurred in ewes which retained sponges for 13 days than at 10 days. The number of ewes lambing and the number of lambs born as a percentage of ewes treated was as high as in later-lambing untreated ewes.
\end{abstract}

In order to stimulate fertile oestrus in anoestrous ewes the priming dose of a progestagen is usually administered either by injection or orally. However, Robinson (1964) and Roberts (1966), working with cyclic Merino ewes, reported the use of vaginal sponges for applying progestagens to ewes. In view of the high degree of synchronization achieved with sponges, the present study was planned to investigate their use in conjunction with pregnant mare's serum gonadotrophin (PMSG) to stimulate fertile oestrus in anoestrous Romney ewes during the early summer.

In addition, a single intra-muscular injection of 6-methyl-17-acetoxyprogesterone (MAP) dissolved in propylene glycol was tested as an alternative to sponges for progestational priming.

One hundred and twenty, 7- and 8-year-old Romney ewes located at Hamilton, New Zealand, were weaned from their lambs at shearing in the first week of December 1964.

Vaginal sponges (Roberts, 1966) were impregnated with progesterone or MAP at a dose of $400 \mathrm{mg}$ or $40 \mathrm{mg}$ respectively. The sponges were inserted into the ewes' vaginae on Day 0 (9th December) for 10 or 13 days to compare the effectiveness of the two periods of insertion. Injections of 1000 i.u. of PMSG/ewe were given subcutaneously to the fifteen ewes of each sub-group on the day of sponge removal and also 16 days later.

Ewes were inspected daily from 10th December 1964 to 2nd March 1965 to identify those which had been marked by six crayon-harnessed Southdown rams running with them. The incidence of oestrus and lambing was compared with that in two other groups each of thirty ewes. One group received a single 
intra-muscular injection of $3.0 \mathrm{mg}$ MAP dissolved in $1 \mathrm{ml}$ of propylene glycol (Day 0 ) followed on the 10 th and 26 th days by 1000 i.u. of PMSG. The second group received no treatment and served as an experimental control.

The patterns of mating are presented in Table 1 for the six groups of ewes.

The most successful treatments in terms of synchronized mating appear to be $40 \mathrm{mg}$ MAP sponges (Group 4) and $400 \mathrm{mg}$ progesterone sponges (Group 2) inserted for 13 days. All fifteen ewes in Group 4 and thirteen of the fifteen in Group 2 mated on the 2 days, 24th and 25th December. The ewes in Group 6, which received no hormonal treatment, mated during the period from the 15th January, Day 37, until 22nd February, Day 75.

The distribution of lambing dates for the various groups is presented in

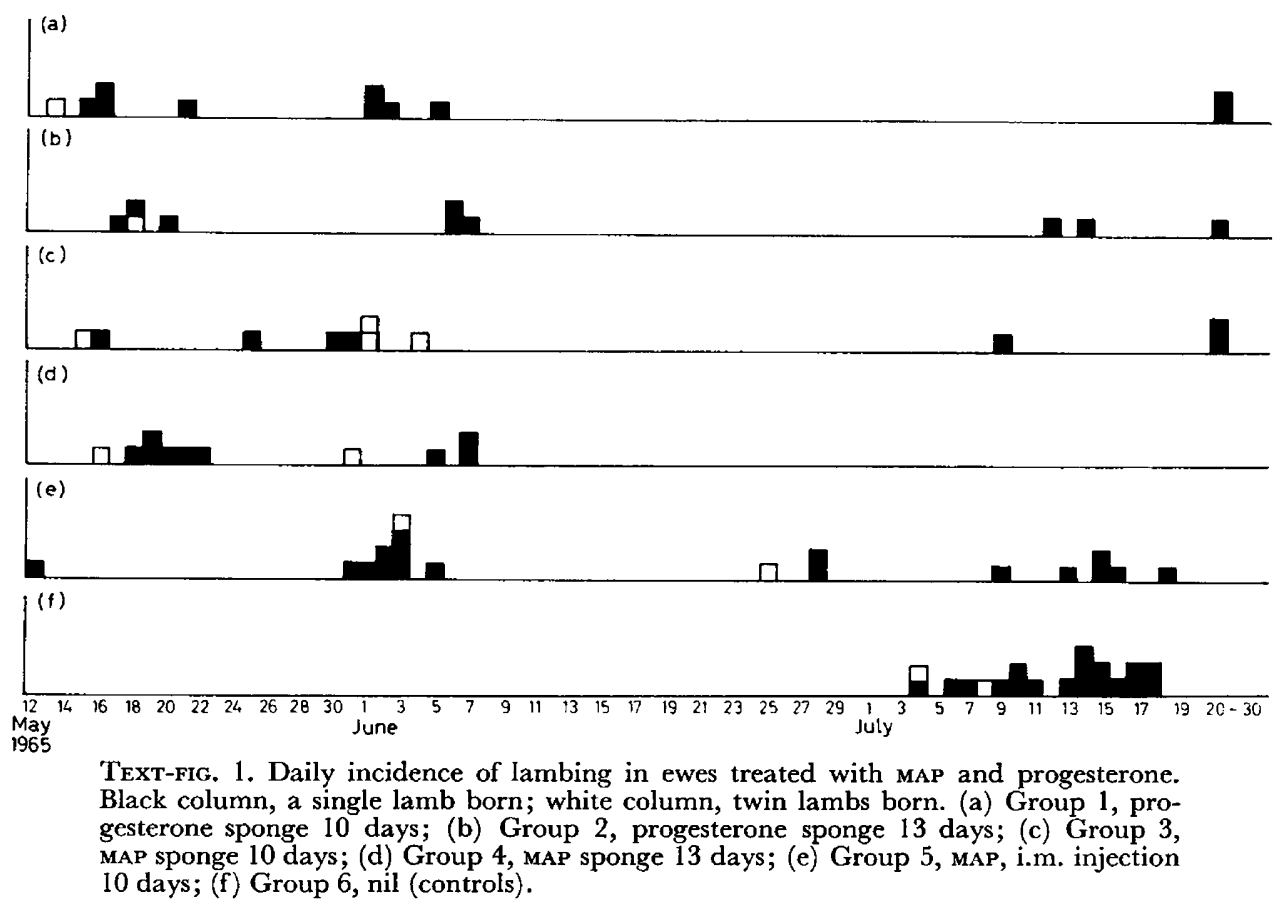

Text-fig. 1. The distribution of lambing dates in Text-fig. 1 indicates that while all ewes in Group 4 (MAP sponges for 13 days) lambed to their first or second mating in a period of 22 days, the other groups contained ewes which lambed at the third, fourth or fifth cycle after the first peak of mating. In all groups, other than Group 4, many of these later lambing ewes did not lamb earlier than the untreated controls. The small number of ewes lambing to first and second PMSG injection in each group does not warrant statistical analysis to test whether differences are significant. However, the percentage of ewes lambing and the percentage of lambs born of the MAP sponge groups ( 3 and 4) are not less than those of Group 6, the untreated ewes which lambed 6 weeks later.

It appears that the use of MAP or progesterone gives greater synchronization of oestrus after 13 days than does the insertion of sponges after 10 days. This 
Oestrus in Romney ewes. I

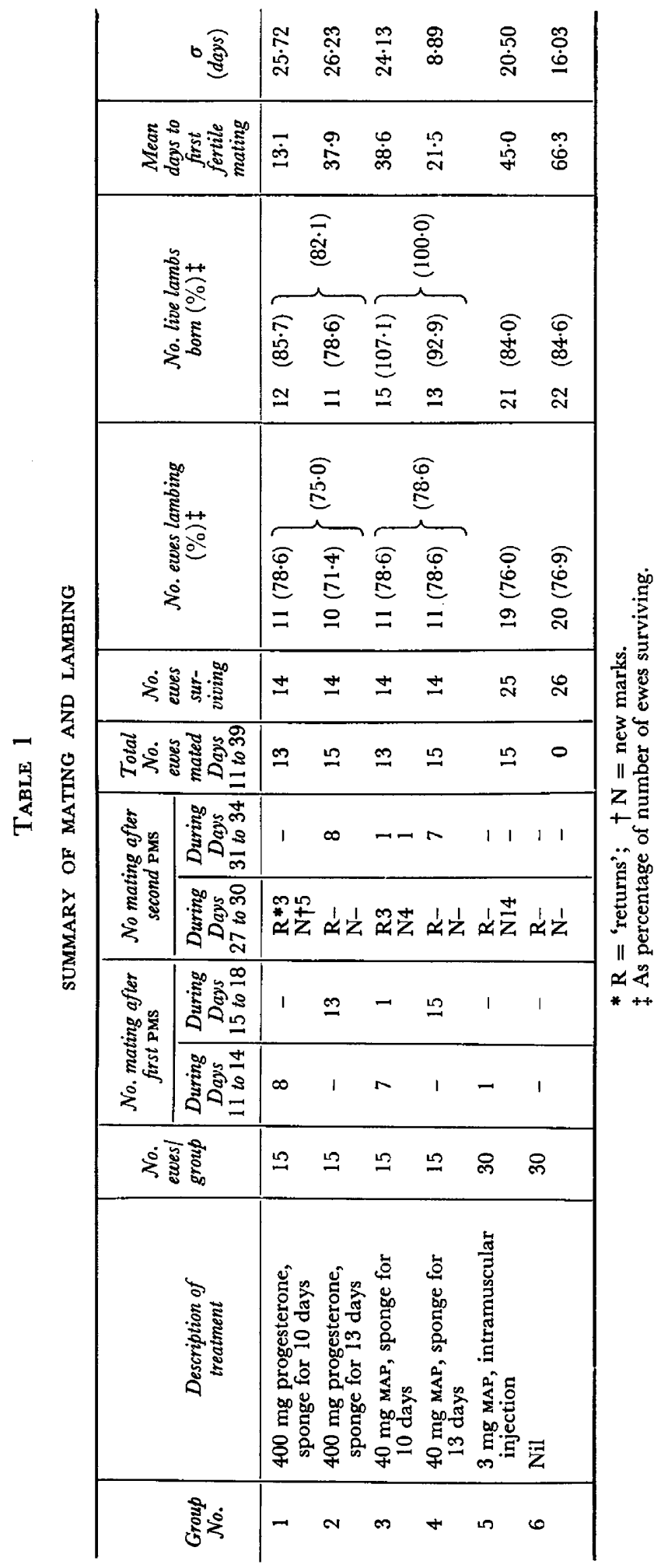


finding may be peculiar to the dose rates of the two progestagens used but it may be optimum for maximum conception to have a 13-day period of progestagen priming during anoestrus similar to the 13-day advantage found by Roberts (1966) during the breeding season.

There is little difference between MAP and progesterone at first oestrus in the percentage of ewes mating where thirteen of the fifteen ewes treated for the same period with MAP sponges mated in 2 days. However, eight of the former (i.e. $61.5 \%$ ) and seven of the latter $(46.6 \%$ ) returned to the ram following the second PMSG injections.

The mean intervals to fertile oestrus in Table 1 are essentially mean intervals to lambing if the length of pregnancy in days is added. Similarly, the synchronization of lambing dates is a reflection of the low standard deviation of days to first fertile mating.

It may be concluded, therefore, that of the four sponge groups, $40 \mathrm{mg}$ of MAP is the best treatment to achieve a concentrated lambing with the maximum number of ewes conceiving to the first mating.

The use of gonadotrophin, PMSG, at the relatively high dose of 1000 i.u., might have been expected to produce multiple ovulation and hence multiple births in the treated ewes. However, there were relatively few twins born in either the treated or control ewes, while lambing was reported by the shepherds to be significantly free of lambing abnormalities and of the need for assistance to the parturient ewe. Death rates in treated ewes were slightly less than in control ewes suggesting no deleterious effect on ewe survival. The management problem of ewes rearing lambs through a New Zealand winter does not appear to have been excessive. The ewes were pastured at the rate of five ewes per acre and the death rates of treated ewes' lambs after birth were less than those of the control ewes lambing nearer the spring.

In conclusion, the present trial demonstrates a successful method of supplying anoestrous Romney ewes with an abruptly terminating source of progestagen. The withdrawal of MAP after 13 days coinciding with a subcutaneous injection of 1000 i.u. of PMSG has resulted in a high degree of synchronized fertile oestrus. The injection of a further 1000 i.u. of PMSG 16 days after the first, stimulated a second fertile oestrus in those ewes which, supposedly, had not conceived. The ewes receiving MAP for 13 days, which conceived at either the first or second oestrus, lambed in the autumn/early winter (May/June), lambs produced by ewes mated being $93 \%$.

The authors wish to thank Mr A. E. Uljee and Miss S. A. Pierard for assistance in the conduct of the experiments. $\mathrm{Mr} \mathrm{D}$. A. Bilkey co-operated in the initial planning and execution of the trial. Supplies of MAP (Repromap) were made available by Upjohn (Pty.) Ltd.

\section{REFERENCES}

Roserts, E. M. (1966) The use of intra-vaginal sponges impregnated with 6-methyl-17-acetoxyprogesterone (MAP) to synchronize ovarian activity in cyclic Merino ewes. Proc. Aust. Soc. Anim. Prod. 6, 32.

Robinson, T. J. (1964) Synchronization of oestrus in sheep by intravaginal and subcutaneous application of progestin impregnated sponges. Proc. Anim. Prod. 5, 47. 